\title{
СТРОЕНИЕ И ЭЛЕКТРОХИМИЧЕСКИЕ СВОЙСТВА КОМПЛЕКСНЫХ СОЕДИНЕНИЙ МЕТАЛЛОВ С ДИГИДРОКВЕРЦЕТИНОМ
}

\author{
() Н.Н. Трофимова ${ }^{\prime *}$, Е.В. Столповская ${ }^{I}$, В.А. Бабкин ${ }^{1}$, С.В. Федоров ${ }^{1}$, Г.А. Калабин ${ }^{2}$, \\ С.В. Горяинов ${ }^{2}$, Е.Е. Золотарев ${ }^{1}$, А.Ю. Сарронов ${ }^{3}$, А.В. Качевский ${ }^{3}$ Р.Г. Житов ${ }^{3}$ \\ ${ }^{1}$ Иркутский институт химии им. А.Е. Фаворского СО РАН, ул. Фаворского, 1, \\ Иркутск, 664033 (Россия), e-mail: natrof@inbox.ru \\ ${ }^{2}$ Российский университет дружбы народов, ул. Миклухо-Маклая, 8/2, Москва, \\ 117198 (Россия) \\ ${ }^{3}$ Иркутский государственный университет, ул. Карла Маркса, 1, Иркутск, \\ 664003 (Россия)
}

Изучено взаимодействие ионов двухвалентных металлов с транс-2R3R-дигидро-2-(3,4-дигидроксифенил)-3,5,7тригидрокси-4Н-1-бензопиран-4-оном (дигидрокверцетином, 1), приводящее к образованию комплексных соединений цинка (2), меди(II) (3) и кальция (4). Методами ИК, ЯМР спектроскопии, масс-спектрометрии DART, термогравиметрического, элементного и рентгеноспектрального энергодисперсионного микроскопического анализов определено строение полученных комплексных соединений. Показано, что соединение 2 имеет структуру $\left[\mathrm{ZnL}_{2}\left(\mathrm{H}_{2} \mathrm{O}\right)_{2}\right]$, где $\mathrm{L}$ - депротонированный дигидрокверцетин. Для комплекса 3 установлена структура $\left[\mathrm{CuLOH}\left(\mathrm{H}_{2} \mathrm{O}\right)\right]$, для комплекса 4 предложена структура $\left[\mathrm{CaLOH}\left(\mathrm{H}_{2} \mathrm{O}\right)\right]$. В полученных соединениях определены наиболее вероятные сайты связывания флавоноидного лиганда металлом. В цинковом комплексе 2 оба флавоноидных лиганда L координированы к иону цинка через кислородный атом гидроксильной группы при С-7. В комплексном соединении 3 связывание флавоноидного лиганда ионом меди(II) осуществляется по положению 3-ОН- 4-C=O. В комплексе 4 равновероятно комплексообразование по двум местам связывания флавоноидного лиганда ионом кальция: с участием кислородного атома при С-4' и/или кислородного атома гидроксильной группы при С-7 в кольце А. Методом циклической вольтамперометрии на графитовом электроде в ДМСО изучены окислительно-восстановительные свойства полученных комплексных соединений.

Ключевые слова: комплексные соединения цинка, меди(II), кальция с дигидрокверцетином, структура, циклическая вольтамперометрия.

Работа выполнена при финансовой поддержке Программы РАН «Фундаментальные науки - медицине» на 2013-2015 г2, проект «Разработка инноваџионного препарата для комбустиологии на основе продуктов комплексной переработки биомассы лиственницы сибирской» (ФНМ-2012-02). Основные результаты исследования получены с использованием материально-технической базы Байкальского аналитического ичентра коллективного пользования СО РАН.

\section{Введение}

Трофимова Наталья Николаевна - старший научный сотрудник лаборатории химии древесины, кандидат химических наук, тел.: (3952) 42-24-25,

e-mail: natrof@inbox.ru, natrof@ irioch.irk.ru Столповская Елена Владимировна - младший научный сотрудник лаборатории химии древесины, тел.: (3952) 42-24-25, e-mail:stel@ irioch.irk.ru Бабкин Василий Анатольевич - заведующий лабораторией химии древесины, доктор химических наук, профессор, тел./факс: (3952) 51-14-27, e-mail: babkin@irioch.irk.ru

Федоров Сергей Владимирович - научный сотрудник лаборатории структурной химии, тел./факс: (952) 4248-71, e-mail:sefed@irioch.irk.ru

Продолжение на с. 122
Комплексные соединения (КС) металлов, где в качестве лигандов (L) выступают депротонированные молекулы природных полифенолов, и в частности, флавоноидов [1-14], все больше привлекают внимание исследователей благодаря фармакологической перспективности новых соединений их основе $[15,16]$.

Несмотря на доступность, транс-2R,3R-2,3дигидро-2-(3,4-дигидроксифенил)-3,5,7-тригидрокси4H-1-бензопиран-4-он (дигидрокверцетин, ДКВ, 1) в реакциях комплексообразования с ионами металлов изучен мало: исследовано его взаимодействие с ионами натрия, калия, меди (II) [17-18], цинка [5],

\footnotetext{
* Автор, с которым следует вести переписку.
} 
железа (II) и (III) [19]. Комплексы меди (II), железа (II) и (III) были охарактеризованы как более сильные антиоксиданты по отношению к ДКВ [19], однако во всех случаях невозможно отнести эту активность к определенной структуре комплексного соединения и определить взаимодействие с ионами натрия, калия, меди (II) [17-18], цинка [5], железа (II) и (III) [19]. Комплексы меди (II), железа (II) и (III) были охарактеризованы как более сильные фрагмент молекулы (или заместитель), отвечающий за усиление антиоксидантной активности.

Ранее нами были получены и предварительно охарактеризованы комплексные соединения цинка, меди(II) и кальция [20, 21], проявляющие биологическую активность [22, 23].

Цель данной работы ревизия структур комплексных соединений, цинка (2), меди (II) (3) и кальция с ДКВ (4) на основании данных ИК и 2D ЯMP спектроскопии, масс-спектрометрии DART, элементного и рентгеновского спектрального энергодисперсионного микроскопического анализов (РСЭДМА), термогравиметрии (ТГ) и изучение электрохимических свойств полученных КС методом циклической вольтамперометрии.<smiles>CC1(O)C(=O)[C@@H](c2ccc(O)c(O)c2)Oc2cc(O)cc(O)c21</smiles>

1<smiles>O=C1c2c(O)cc(O[14C](O)(O)Oc3cc(O)c4c(c3)O[C@H](c3ccc(O)c(O)c3)[C@@H](O)C4=O)cc2O[C@H]1c1ccc(O)c(O)c1</smiles>

2<smiles>CCC(C)C(=O)Oc1cc(O)c2c(c1)O[C@H](c1ccc(O)c(O)c1)C(O)C2=O</smiles>

\section{Экспериментальная часть}

рН-метрию проводили на приборе «Эксперт-рН». ИК-спектры записывали на приборе «Bruker Vertex» 70 в таблетке с $\mathrm{KBr}\left(2,5\right.$ мг/300 мг KBr). Спектры ЯМР растворов соединений в ДМСО- $d_{6}$ регистриро-

Калабин Геннадий Александрович - директор центра Прима ЦКП (НОЦ) РУДН, e-mail: kalabinga@mail.ru Горяинов Сергей Владимирович - заведующий лабораторией масс-спектрометрии и спектроскопии ЯМР высокого разрешения центра Прима ЦКП (НОЦ) РУДН, e-mail: goryainovs@list.ru Золотарев Егор Евгеньевич - инженер лаборатории химии древесины, тел.: (3952) 42-24-25, e-mail: egorzolotarev@yandex.ru Сафронов Александр Юрьевич - заведующий кафедрой общей и неорганической химии, доктор химических наук, профессор, тел.: (3952) 91-57-89,

e-mail: dean@chem.isu.ru

Кашевский Алексей Валерьевич - доцент кафедры общей и неорганической химии, кандидат химических наук, e-mail: Caribcar@mail.ru

Житов Роман Георгиевич - младший научный сотрудник лаборатории полимеризационных процессов и органического синтеза, кандидат химических наук, e-mail: zhitov@rambler.ru вали при температуре $26{ }^{\circ} \mathrm{C}$. Спектры ЯМР ${ }^{13} \mathrm{C}$ образцов регистрировали на приборе «Bruker DPX 400» с рабочей частотой 100,6 МГц. Использовали многократное накопление на полосе 28000 Гц при времени выборки данных 1,2 с и с релаксационной задержкой 7 с. Спектры ${ }^{1} \mathrm{H}$ и двумерные спектры ЯMP COSY, HSQC, HMBC регистрировали на приборе «Bruker Avance» с рабочей частотой 400,1 Гц. Для регистрации спектров ${ }^{1} \mathrm{H}$ использовали 16-кратное накопление сигналов на полосе 8012 Гц при времени выборки данных 2,04 с и с релаксационной задержкой 2 с. Двумерные спектры регистрировали с использованием импульсных градиентов поля с временем выборки данных 0,14 с и от 256 до 1024 прохождений по координате $\mathrm{t}_{1} \mathrm{c}$ релаксационной задержкой $1,5 \mathrm{c}$; по координате $\mathrm{t}_{2}$ время выборки данных составляло 
0,14 с (COSY), 0,03 с (HSQC) и 0,07 с (HMBC) и от 512 до 2048 прохождений. В эксперименте HSQC для наблюдения максимальных амплитуд кросс-пиков использовалась константа ${ }^{1} J_{\mathrm{CH}}=140$ Гц, а для эксперимента НМВС использовалось значение константы ${ }^{\mathrm{n}} J_{\mathrm{CH}}=4$ Гц.

Масс-спектрометрию MALDI проводили на масс-спектрометре Bruker autoflex speed, оснащенном твердотельным УФ-лазером с $\lambda=355$ нм и рефлектроном с использованием четырех матриц: 3-индолакриловая кислота (IAA), 2,5-дигидроксибензойная кислота (DHB), 1,8,9-антрацентриол (АТ), 2-(4гидроксифенилазо)бензойная кислота (НАВА). Навеску образца растворяли в ДМСО, отбирали 20 мкл раствора и добавляли 20 мкл раствора матрицы в ТГФ (30 мг/мл). 1 мкл смеси наносили на металлическую подложку, выжидали до момента улетучивания растворителя и регистрировали масс-спектры. Массспектрометрию DART проводили на времяпролетном масс-спектрометре JMS-T100LP AccuTOF в диапазоне 100-1000 Да в температурном диапазоне (от 150 до $300{ }^{\circ} \mathrm{C}$ ) при скоростях газа от 0,5 до 3 л/мин. Наилучшего соотношения сигнал/шум удалось добиться в режиме регистрации отрицательных ионов при скорости потока 1 мл/мин и температуре источника $300{ }^{\circ} \mathrm{C}$, в режиме регистрации положительных ионов зарегистрировать масс-спектры комплексов не удалось.

РСЭДМА выполнен с помощью электронного микроскопа фирмы Hitachi марки ТМ 3000, датчик: Xray детектор SDD XFlash 430-H. Термогравиметрический анализ осуществляли на приборе синхронного термического анализа STA 449 F3 Jupiter фирмы Netzsch в динамическом режиме (скорость нагрева образца 5 град/мин) в токе азота (скорость подачи газа 30 мл/мин).

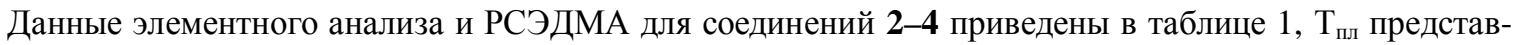
лены в таблице 2 , данные ${ }^{13} \mathrm{C}$ и ${ }^{1} \mathrm{H}$ ЯМР-спектров приведены в таблице 3.

Синтезы соединений 2, 3 проводили, как описано ранее [20-25].

Комплексное соединение $\left[\mathrm{ZnL}_{2}\left(\mathrm{H}_{2} \mathrm{O}\right)_{2}\right]$ (2). Выход 75\%. Зеленовато-желтый мелкокристаллический порошок нерастворим в воде, этаноле, ацетоне. Мало растворим в ДМСО (C=10 $0^{-2}-10^{-3}$ г/мл) [26]. ИК-

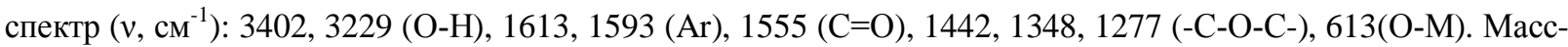

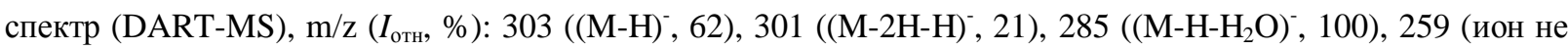
идентифицирован (н.и.), 29), 177 (н.и., 16), 153 (н.и., 16).

Комплексное соединение [CuLOH(H2)] (3). Выход 80 \%. Зеленовато-коричневый мелкокристаллический порошок нерастворим в воде, этаноле, ацетоне. Очень мало растворим в ДМСО, С $=10^{-3}-10^{-4}$ г/мл

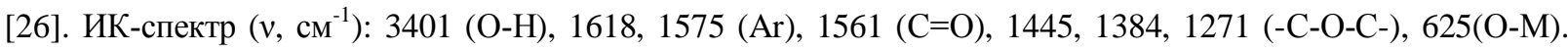

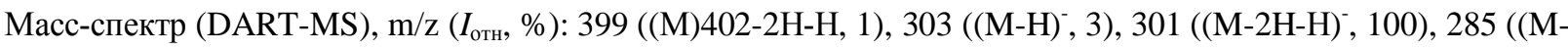
Н-Н $\left.\left.{ }_{2} \mathrm{O}\right)^{-}, 16\right), 259$ (н.и., 2), 193 (н.и., 3), 179 (н.и., 7), 153 (н.и., 1).

Синтез комплексного соединения $\left[\mathrm{CaL}(\mathrm{OH})\left(\mathrm{H}_{2} \mathrm{O}\right)\right](4)$. В нагретый до $80{ }^{\circ} \mathrm{C}$ водный раствор дигидрокверцетина $(1,0 \mathrm{M})$ добавляли при постоянном перемешивании водный раствор ацетата кальция (2,0 M), выдерживали течение 1 ч при контроле рН раствора, равного 8,0, в начале и в конце реакции. Осадок отфильтровывали на стеклянном пористом фильтре под вакуумом, промывая горячей водой и затем этанолом для удаления следов исходных реагентов, высушивали в сушильном шкафу при $105^{\circ} \mathrm{C}$ до постоянной массы. Получали мелкокристаллический порошок зеленовато-коричневого цвета комплекса 4. Выход - 60\%. Осадок нерастворим в воде, этаноле, ацетоне. Очень малорастворим в ДМСО, С=10-3 г/мл [26].

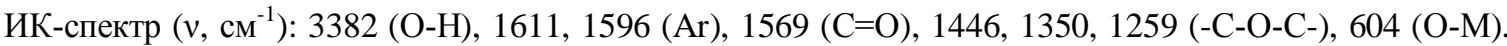

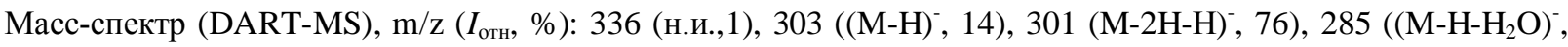
44), 255 (н.и., 100), 227 (н.и., 26), 219 (н.и., 18), 193 (н.и., 34), 179 (н.и., 29), 153 (н.и., 78 ).

Электрохимические измерения проводили на установке на базе потенциостата IPC-pro M (Россия), включающей: трехэлектродную ячейку объемом 50 мл; графитовый рабочий электрод с площадью видимой поверхности $0,39 \mathrm{~cm}^{2}$, хлорсеребряный электрод сравнения BAS RE-1, где внутренний раствор был заменен на насыщенный раствор $\mathrm{AgCl}$ и $\mathrm{KCl}$ по методике [27]; платиновый вспомогательный электрод. Концентрация исследованных веществ составляла $5 \cdot 10^{-3}$ моль. Перед измерением вольтамперограмм раствор в ячейке продували аргоном в течение 10 мин. Все эксперименты выполнены при комнатной температуре. В качестве фонового электролита использовался $10^{-1}$ моль раствор $\mathrm{LiClO}_{4}$ в ДМСО. Циклические вольтамперограммы в фоновом растворе измерялись при скорости развертки потенциала 5, 20, 50 мВ/с, затем измерялись циклические вольтамперограммы в растворе металлокомплекса при скоростях развертки потенциала 2, 5, 10, 20, 50, 100, 200, 500 мB/с. 


\section{Обсуждение результатов}

Анализ ИК- и 2D ЯМР-спектров соединений 2-4 и сравнение с данными для 1 показали сохранение нативности структуры флавоноидного лиганда и комплексообразование, исключающее окисление, рацемизацию и другую деструкцию базовой молекулы.

Для определения молекулярной массы соединений 2-4 использованы десорбционные методы массспектрометрии MALDI и DART. При анализе образцов методом масс-спектрометрии MALDI, проведенном в режиме регистрации отрицательных и положительных ионов, записать масс-спектры комплексов не удалось. Масс-спектры образцов были получены методом масс-спектрометрии DART после подбора условий анализа в режиме регистрации отрицательных ионов.

Macc-спектры DART соединений 2-4 не содержат депротонированных молекулярных ионов (повидимому, они нестабильны даже в условиях «мягкой» ионизации DART). Действительно, получение информативных масс-спектров для комплексов металлов с флавоноидами не всегда возможно по разным причинам [28]. В спектрах 2-4 наиболее интенсивными являются пики с m/z 303 и m/z 301, соответствующие депротонированному молекулярному иону (М-Н)- ДКВ и, по-видимому, продукту элиминирования двух атомов водорода из него (процесс дегидрирования исходного образца в источнике наблюдался нами ранее в масс-спектрах нескольких спиртов). Кроме того, в масс-спектрах всех КС содержатся характеристичные пики с m/z 285 и 152, соответствующие фрагментации флавононолов: иону $\left(\mathrm{M}-\mathrm{H}-\mathrm{H}_{2} \mathrm{O}\right)^{-}$и иону $\mathrm{B}_{3}^{+{ }^{+\cdot}}$ [29].

Брутто-формулы соединений 2-4 и их молярные массы (M), стехиометрическое соотношение металл : флавоноидный лиганд (Met:L) в составе комплексных соединений определены на основании данных элементного и РСЭДМА (табл. 1) с учетом содержания кристаллизационной воды в составе исходного ДКВ и КС по данным термогравиметрического анализа (табл. 2).

Действительно, для флавоноидов характерно образование кристаллогидратов с различным содержанием воды. Так, в [30] было показано, что образцы ДКВ и препарата диквертин образовывают кристаллогидраты, содержащие от 0,5 до 1,3\% связанной воды, различающейся температурными интервалами ее удаления и по величинам энтальпии фазовых переходов. Рентгеноструктурный анализ кристаллов ДКВ из водно-этанольного раствора показал вхождение в кристаллическую ячейку 2 независимых молекул ДКВ с пятью молекулами воды [31].

Таблица 1. Найденные и вычисленные значения содержания элементов для $\mathbf{2 - 4}$, их состав и молекулярная масса

\begin{tabular}{|c|c|c|c|c|c|}
\hline \multirow{3}{*}{$\begin{array}{l}\text { Соеди } \\
\text { нение }\end{array}$} & \multirow{3}{*}{ Элемент } & \multicolumn{3}{|c|}{ Содержание, \% } & \multirow{3}{*}{$\begin{array}{c}\text { Состав комплекса, M } \\
\text { (г/моль })\end{array}$} \\
\hline & & \multicolumn{2}{|c|}{ Найдено } & \multirow{2}{*}{ Вычислено для: } & \\
\hline & & Элементный анализ & РСЭДМА & & \\
\hline 2 & $\begin{array}{c}\mathrm{C} \\
\mathrm{H} \\
\mathrm{O} \\
\mathrm{Zn}\end{array}$ & $\begin{array}{c}49,7 \\
3,7 \\
- \\
8,5 \\
\end{array}$ & $\begin{array}{c}48,2 \\
- \\
44,1 \\
7,7 \\
\end{array}$ & $\begin{array}{c}\mathrm{C}_{30} \mathrm{H}_{26} \mathrm{O}_{16} \mathrm{Zn} \\
50,9 \\
3,7 \\
36,2 \\
9,2\end{array}$ & $\begin{array}{c}{\left[\mathrm{ZnL}_{2}\left(\mathrm{H}_{2} \mathrm{O}\right)_{2}\right]} \\
\mathrm{M}(707)\end{array}$ \\
\hline 3 & $\begin{array}{c}\mathrm{C} \\
\mathrm{H} \\
\mathrm{O} \\
\mathrm{Cu} \\
\end{array}$ & $\begin{array}{c}46,5 \\
3,3 \\
- \\
16,2 \\
\end{array}$ & $\begin{array}{c}45,0 \\
- \\
37,9 \\
16,9 \\
\end{array}$ & $\begin{array}{c}\mathrm{C}_{15} \mathrm{H}_{14} \mathrm{O}_{9} \mathrm{Cu} \\
44,8 \\
3,5 \\
35,8 \\
15,9\end{array}$ & $\begin{array}{c}{\left[\mathrm{CuLOH}\left(\mathrm{H}_{2} \mathrm{O}\right)\right]} \\
\mathrm{M}(402)\end{array}$ \\
\hline 4 & $\begin{array}{c}\mathrm{C} \\
\mathrm{H} \\
\mathrm{O} \\
\mathrm{Ca}\end{array}$ & $\begin{array}{c}43,1 \\
4,1 \\
- \\
9,9\end{array}$ & $\begin{array}{c}44,1 \\
- \\
44,2 \\
11,5\end{array}$ & $\begin{array}{c}\mathrm{C}_{15} \mathrm{H}_{14} \mathrm{O}_{9} \mathrm{Ca} \\
47,6 \\
3,7 \\
38,1 \\
10,6 \\
\end{array}$ & $\begin{array}{c}{\left[\mathrm{CaL}(\mathrm{OH})\left(\mathrm{H}_{2} \mathrm{O}\right)\right], \mathrm{M}} \\
(378)\end{array}$ \\
\hline
\end{tabular}

Таблица 2. Температурные интервалы и потеря массы при термогравиметрии соединений 1-4

\begin{tabular}{c|c|c|c|c|c}
\hline \multirow{2}{*}{ Образец } & \multirow{2}{*}{ Т. пл., ${ }^{\circ} \mathrm{C}$} & \multicolumn{2}{|c|}{ Пик 1} & \multicolumn{2}{|c}{ Пик 2} \\
\cline { 2 - 5 } & 228 & $\Delta \mathrm{t},{ }^{\circ} \mathrm{C}$ & $\Delta \mathrm{m}, \%$ & $\Delta \mathrm{t},{ }^{\circ} \mathrm{C}$ & $\Delta \mathrm{m}, \%$ \\
\hline $\mathbf{1}$ & $200 \pm 5$ & $80-126$ & 2,8 & - & - \\
$\mathbf{2}$ & $241 \pm 7$ & $120-170$ & $3,0 \pm 0,86$ & $180-215$ & $2,47 \pm 0,90$ \\
$\mathbf{3}$ & $243 \pm 5$ & $110-140$ & $2,0 \pm 0,28$ & $190-230$ & $1,14 \pm 0,20$ \\
$\mathbf{4}$ & $100-180$ & 5,7 & - & - \\
\hline
\end{tabular}


При сопоставлении ИК-спектров комплексов 2-4 со спектрами ДКВ отмечены изменения полос поглощений в областях 605-650, 1700-1350 см-1. В ИК-спектрах 2, 3, 4 появляются новые полосы при 613, 625 и 604 см$^{-1}$, соответственно, относящиеся к валентному колебанию связи Меt-О, и свидетельствующие о формировании координационной связи иона металла с кислородными атомами гидроксильных групп флавоноидного лиганда [32]. Значения максимумов поглощений этих полос смещены на 3-14 см ${ }^{-1}$ в низкочастотную область по сравнению с v(Met-O) ацетатов цинка, меди (II) и кальция (622, 629 и 618 см-1, соответственно), механических смесей ДКВ с каждой из солей в соотношениях 1 : 1 моль $(622,628,617$ см-1, соответственно). На образование КС также указывают существенные батохромные сдвиги (до $70 \mathrm{~cm}^{-1}$ ) максимумов поглощений полос свободной карбонильной группы и положения полос поглощения гидроксильных групп, связанных внутримолекулярными и межмолекулярными водородными связями в области 3346$3436 \mathrm{~cm}^{-1}$ [32]. Сдвиг полосы поглощения валентных колебаний карбонильной группы в область низких частот по отношению к $1638 \mathrm{~cm}^{-1}$ для 1 (1555, 1561, $1569 \mathrm{~cm}^{-1}$ для $\mathbf{2}, \mathbf{3}, \mathbf{4}$, соответственно) свидетельствует об ионизации группы $\mathrm{C}=\mathrm{O}$ вследствие введения электроноакцепторного заместителя независимо от положения комплексообразования [32-34].

Структуры соединений 2 и 4, проявляющих диамагнитные свойства, установлены методом ЯМР. Полное отнесение сигналов в спектрах ЯМР ${ }^{1} \mathrm{H}$ и ${ }^{13} \mathrm{C}$, характер их мультиплетности, интегральная интенсивность и положение сигналов в спектрах (табл. 3) проведено на основании их сравнения с данными для ДКВ, в том числе литературными [35], поддержано данными двумерных экспериментов COSY, HMBC, HSQC и приводится впервые.

В ПМР спектрах 2 КССВ протонов Н-2 и Н-3, равная 11,0 Гц, соответствует транс-положению этих протонов при C-2 и С-3 асимметрических атомах в плоскости гетерокольца флавоноидной части молекулы, а $2 R, 3 R$-конфигурация хиральных центров C-2 и С-3 следует из соответствия значений констант спинспинового взаимодействия (КССВ) и химических сдвигов (ХC) H-2 и Н-3 для транс-2R,3R-2,3-дигидро-2(3,4-дигидроксифенил)-3,5,7-тригидрокси-4H-1-бензопиран-4-она [29, 35].

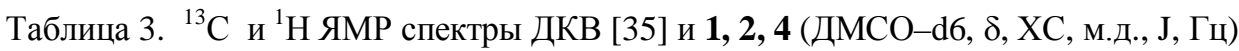

\begin{tabular}{|c|c|c|c|c|c|c|c|c|}
\hline \multirow[t]{2}{*}{ Атомы } & \multicolumn{2}{|c|}{ ДКВ [35] } & \multicolumn{2}{|c|}{ Соединение 1} & \multicolumn{2}{|c|}{ Соединение 2} & \multicolumn{2}{|c|}{ Соединение 4} \\
\hline & $\mathrm{C}$ & $\mathrm{H}$ & $\mathrm{C}$ & $\mathrm{H}$ & $\mathrm{C}$ & $\mathrm{H}$ & $\mathrm{C}$ & $\mathrm{H}$ \\
\hline 2 & 83,10 & $\begin{array}{c}\text { 4,973, д., } \\
11.1\end{array}$ & 83,1 & $\begin{array}{c}\text { 4,99, д., } \\
11,3\end{array}$ & 83,1 & $\begin{array}{c}\text { 4,96, д., } \\
11,0\end{array}$ & 82,6 & $\begin{array}{c}4,70, \text { д., } \\
10,5\end{array}$ \\
\hline 3 & 71,62 & $\begin{array}{c}4,483 \text {, д.д., } \\
6,1 \text { и } 11,1\end{array}$ & 71,6 & $\begin{array}{l}4,52, \text { д.Д., } \\
6,0 \text { и } 11,3\end{array}$ & 71,6 & $\begin{array}{l}4,47, \text { д.Д., } \\
6,2 \text { и } 11,0\end{array}$ & 71,4 & $\begin{array}{c}4,21, \text { д., } \\
10,39\end{array}$ \\
\hline 4 & 197,78 & - & 197,7 & - & 197,6 & - & 198,9 & - \\
\hline $4 a$ & 100,53 & - & 100,5 & - & 100,4 & - & 99,3 & - \\
\hline 5 & 163,37 & - & 163,3 & - & 163,4 & - & 163,2 & - \\
\hline 6 & 96,03 & 5,898, д., 2 & 96,0 & $\begin{array}{c}\text { 5,92, д., } \\
2,2\end{array}$ & 96,1 & $\begin{array}{c}\text { 5,88, уш. } \\
\text { с. }\end{array}$ & 96,4 & $\begin{array}{c}5,41, \text { д., } \\
1,35\end{array}$ \\
\hline 7 & 166,83 & - & 166,8 & - & 167,2 & - & 166,8 & - \\
\hline 8 & 95,02 & 5,848, д., 2 & 95,0 & $\begin{array}{c}\text { 5,87, д., } \\
2,0\end{array}$ & 95,1 & $\begin{array}{c}\text { 5,83, уш. } \\
\text { с. }\end{array}$ & 95,8 & $5,37, \mathrm{c}$. \\
\hline $8 \mathrm{a}$ & 162,6 & - & 162,5 & - & 162,6 & - & 163,2 & - \\
\hline $1^{\prime}$ & 128,08 & - & 128,1 & - & 128,1 & - & 128,7 & - \\
\hline $2^{\prime}$ & 115,4 & $6,868, \mathrm{c}$. & 115,3 & 6,90, c. & 115,4 & 6,86, c. & 114,9 & $6,8, \mathrm{c}$. \\
\hline $3^{\prime}$ & 144,98 & - & 145,9 & - & 145,0 & - & 145,1 & - \\
\hline $4^{\prime}$ & 145,81 & - & 145,8 & - & 145,8 & - & 145,7 & - \\
\hline $5^{\prime}$ & 115,17 & 6,72-6,76, & 115,2 & & 115,1 & & 114,9 & \\
\hline $6^{\prime}$ & 119,41 & $\begin{array}{c}2 \mathrm{H}, \mathrm{AB}- \\
\text { система, } \\
8,2\end{array}$ & 119,4 & $\begin{array}{c}6,76, \\
\text { уш.с., } 2 \mathrm{H}\end{array}$ & 119,4 & $\begin{array}{c}6,73, \text { уш. } \\
\text { с., } 2 \mathrm{H}\end{array}$ & 119,0 & $\begin{array}{c}\text { 6,66, } \\
\text { уш.с., } \\
2 \mathrm{H}\end{array}$ \\
\hline $3-\mathrm{OH}$ & & $\begin{array}{c}\text { 5,712, д., } \\
6,1\end{array}$ & & $\begin{array}{c}5,78, \text { д., } \\
6,0\end{array}$ & & $\begin{array}{c}5,71, \text { д., } \\
6,2\end{array}$ & & 5,09, д. \\
\hline $5-\mathrm{OH}$ & & $11,87, \mathrm{c}$. & & $11,90, \mathrm{c}$. & & 11,89 , c. & & $12,1, \mathrm{c}$ \\
\hline 7-O픈 & & $10,78, \mathrm{c}$ & & $10,88, \mathrm{c}$. & & - & & - \\
\hline $3^{\prime}-\overline{\mathrm{OH}}$ & & 8,98, c. & & 9,08 , c. & & 8,99, уш.с. & & - \\
\hline $4^{\prime}-\mathrm{OH}$ & & 8,93, c. & & 9,03 , c. & & 8,99, уш.с. & & - \\
\hline
\end{tabular}


Наиболее существенным для определения положения координации иона металла с флавоноидным лигандом является сопоставление сигналов протонов гидроксильных групп в ПМР спектрах исходного флавоноида и комплексных соединений [36]. Анализ 2D ЯМР спектров ДКВ выявил наличие спинспиновых взаимодействий с ядрами ${ }^{1} \mathrm{H}$ и ${ }^{13} \mathrm{C}$ протонов гидроксильных групп, вступающих во внутримолекулярные водородные связи (рис. 1).

В спектре ЯМР ${ }^{1} \mathrm{H}$ соединения 2 исчезает сигнал при $\delta 10,88$ м.д., принадлежащий протону 7-ОН группы в молекуле 1, что позволяет определить сайт связывания металла по данному положению. Сигналы протонов четырех оставшихся гидроксильных групп соединения 2 в спектре ПМР существенно не изменяют своего местоположения по сравнению с таковыми в спектре дигидрокверцетина. В 2D HМВС спектре 2 протон 5-ОН группы, синглетный сигнал которого находится в самом слабом поле (11,90 м.д.), дает кросспики с атомами C-4a, C-5, C-6 (рис. 1). В 2D COSY спектре соединения 2 наблюдается четкий кросс-пик протона ОН группы при С-3 с Н-3. Эти факты свидетельствуют о том, что координация металла при комплексообразовании не затрагивает данные положения соединения 2. Протоны ОН групп при С-3' и С-4' в данных условиях 2D экспериментов не проявляли никаких взаимодействий.

Совокупность данных, полученных с помощью ИК и ЯМР спектроскопии, элементного анализа, РСЭДМА и ТГ позволяет предложить для соединения 2 наиболее вероятную структуру $\left[\mathrm{ZnL}_{2}\left(\mathrm{H}_{2} \mathrm{O}\right)_{2}\right]$ co стехиометрическим соотношением Met:L, равным 1:2. Сайтом связывания металла с флавоноидным лигандом определено положение -О-С-7.

Синтез кальциевого комплекса с дигидрокверцетином 4 был осуществлен в оптимизированых условия реакции, а именно в водном растворе при рН 8 [37].

В ПМР спектре соединения 4 значения ХС и КССВ протонов Н-2 и Н-3 указывают на сохранение $2 R, 3 R$ абсолютной конфигурации аномерных центров флавоноидной составляющей [29, 35]. В спектре ПМР присутствуют сигналы протонов только двух гидроксильных групп 3-ОН и 5-OH. B 2D HSQC спектре кросс-пики проявляются только для протона 3-ОН.

Таким образом, можно предположить, что хелатирование металла равновероятно происходит по кислородному атому гидроксильной группы при С-7 и/или C-4'. Образование связи Met-O по C-4' положению более вероятно, чем по положению C-3', поскольку протон именно этой гидроксильной группы имеет более высокую степень диссоциации [38].

На основании полученных данных, а также данных ИК-спектроскопии и элементного анализа для комплексного соединения 4 предложена структура $\left[\mathrm{CaL}(\mathrm{OH})\left(\mathrm{H}_{2} \mathrm{O}\right)\right]$ со стехиометрическим соотношением Met : L, равным $1: 1$.

Комплекс меди (II) 3 был охарактеризован нами ранее [20, 21, 23]. Уточнение структуры 3 заключается в определении вхождения гидроксид-иона в качестве второго лиганда при Сu(II) на основании данных элементного анализа, РСЭДМА и ТГ (табл.1 и 2). Кроме того, в масс-спектре 3 наблюдается низкоинтенсивный пик с m/z 399, которому может быть приписана структура $\left(\mathrm{CuLOH}\left(\mathrm{H}_{2} \mathrm{O}\right)-3 \mathrm{H}\right)$.

Одним из основных свойств ДКВ является его антиоксидантная активность, которая связана с окислительно-восстановительными характеристиками ДКВ. Электрохимическое поведение ДКВ и его производных изучено в работах [39-43] методами циклической вольтамперометрии и полярографии с ртутным капающим электродом в различных условиях проведения эксперимента.

Нами проведен сравнительный анализ электрохимической активности соединений 2-4 и исходного флавоноида 1. В связи с очень низкой растворимостью в воде комплексных соединений 2-4, рабочей средой для изучения их электрохимических свойств был выбран ДМСО, в котором все вышеуказанные вещества растворяются при $\mathrm{C}=5 \cdot 10^{-3} \mathrm{M}$.

Циклические вольтамперограммы растворов соединений 1-4 в ДМСО представлены на рисунке 2.

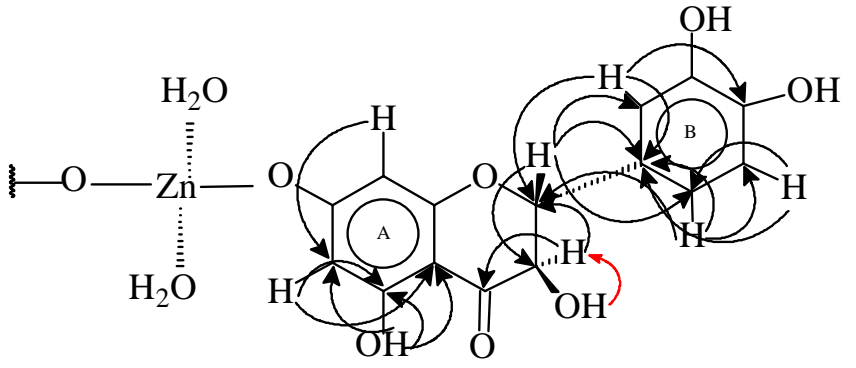

Рис. 1. Наличие гетеро- и гомоядерных корреляций в структурном фрагменте соединения 2 по данным НМВС (черные стрелки) и COSY (красная стрелка) спектроскопии 


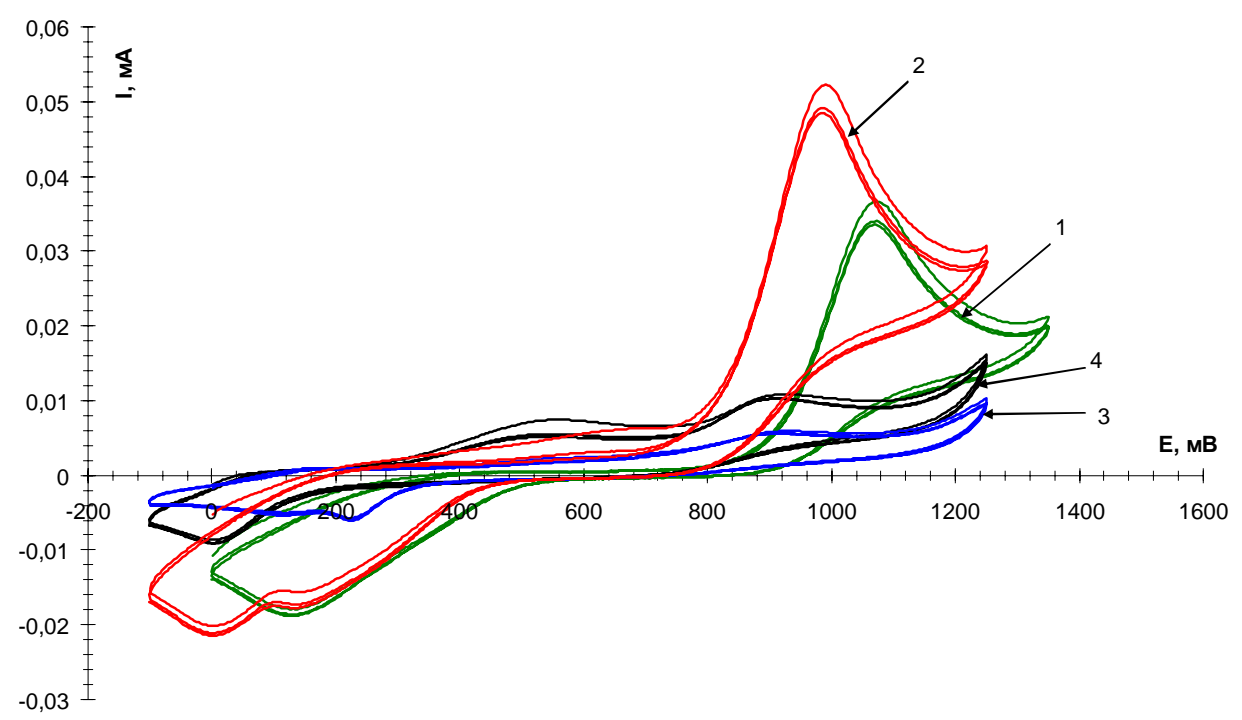

Рис. 2. Циклические вольтамперограммы, измеренные на графитовом электроде в растворах 1-4. Скорость развертки потенциала $-50 \mathrm{MB} / \mathrm{c}, \mathrm{C}=5 \cdot 10^{-3} \mathrm{M}$

Сравнивая электрохимическое поведение ДКВ и его цинкового комплекса 2, можно предполагать следующее: пик при $\approx 980$ мВ отвечает окислению двух остатков ДКВ в молекуле комплексного соединения, что подтверждается как его положением, так и отношением высоты и площади пиков окисления, соответственно, соединений 1 и 2. На катодном ходе кривой для соединения 2 присутствуют два пика восстановления, где один из них совпадает с пиком восстановления ДКВ, а второй смещен в сторону менее положительных потенциалов.

Электрохимическое поведение медного 3 и кальциевого 4 комплексов также отличается от поведения самого ДКВ. Пики окисления соединений 3 и 4 и смещены в область менее положительных потенциалов и менее интенсивны, чем у ДКВ. Пик восстановления у соединения 3 смещен в сторону более положительных потенциалов, а у соединения 4 в сторону менее положительных потенциалов. Оба менее интенсивны по сравнению с пиком восстановления ДКВ в растворе ДМСО.

Вышеприведенные данные свидетельствуют о более сложной природе окислительно-восстановительного поведения исследуемых комплексов 2-4 по сравнению с поведением ДКВ. Необходимо отметить, что цинковый комплекс ДКВ в растворе ДМСО не только сохраняет электрохимическую активность, присущую ДКВ, но и превосходит ее. Электрохимическая активность медного и кальциевого комплексов в растворе ДМСО несколько меньше, чем активность исходного ДКВ. Такое различное электрохимическое поведение комплексов в растворе ДМСО может быть связано как с различными сайтами связывания металлов с флавоноидными лигандами в комплексах, так и с различными способами взаимодействия комплексов с рабочей поверхностью графитового электрода.

\section{Заключение}

Таким образом, на основании данных методов ИК, 2D ЯMP спектроскопии, DART-MS, элементного, рентгеноспектрального энергодисперсионного микроскопического анализов и термогравиметрии предложены наиболее вероятные структуры комплексных соединений цинка (2), меди(II) (3) и кальция (4) с транс-2R3R-дигидро-2-(3,4-дигидроксифенил)-3,5,7-тригидрокси-4H-1-бензопиран-4-оном. Для соединения 2 предложена структура $\left[\mathrm{ZnL}_{2}\left(\mathrm{H}_{2} \mathrm{O}\right)_{2}\right]$, для комплекса 3 - $\left[\mathrm{CuLOH}\left(\mathrm{H}_{2} \mathrm{O}\right)\right.$ и для 4 - $\left[\mathrm{CaL} \mathrm{OH}\left(\mathrm{H}_{2} \mathrm{O}\right)\right]$. В комплексном соединении 2 сайтом связывания металла с лигандом предполагается кислородный атом гидроксильной группы при С-7. В соединении 3 металлосвязывание показано по положению 3-ОН- 4-C=O, а в соединении 4 равновероятны сайты связывания по кислородному атому при С-4' и по кислороду гидроксильной группы в 7 положении кольца А. Методом циклической вольтамперометрии на графитовом электроде в ДМСО изучены окислительно-восстановительные свойства комплексных соединений. 


\section{Список литературы}

1. Черная Н.В., Матяшов В.Г. Экстракционно-фотометрическое определение алюминия в виде кверцетинантипириновых комплексов // Журнал аналитической химии. 1975. Т. ХХХ, №4. С. 698-702.

2. Макашев Ю.А., Шаронов В.П., Миронов В.Е., Макашева И.Е., Блохин В.В. О скоростях образования кверцетиновых и мориновых комплексов переходных металлов // Журнал общей химии. 1975. Т. 45, №12. С. 2748.

3. Макашева И.Е., Мирзаева Л.К., Головкина М.Т. Спектрофотометрическое исследование взаимодействия кверцетина с цинком (II) // Журнал общей химии. 1974. Т. 44, №7. С. 1570-1575.

4. De Souza R.F.V., De Giovani W.F. Synthesis, spectral and electrochemical properties of Al (III) and Zn (II) complexes with flavonoids // Spectrochimica Acta Part A. 2005. Vol. 61. Pp. 1985-1990.

5. Nest G.Le, Caille O., Woudstra M., Roche S., Guerlesquin F., Lexa D. Zn-polyphenol chelation: complexes with quercetin, (+)-catechin, and derivatives: I optical and NMR studies // Inorganica Chimica Acta. 2004. Vol. 357. Pp. 775-784.

6. Panhwar Q.K., Memon Sh., Bhanger M.I. Synthesis, characterization, spectroscopic and antioxidation studies of $\mathrm{Cu}$ (II)-morin complex // Journal of Molecular Structure. 2010. Vol. 967. Pp. 47-53.

7. Panhwar Q.K., Memon Sh. Synthesis and evaluation of antioxidant and antibacterial properties of morin complexes // Journal of Coordination Chemistry. 2011. Vol. 64, N12. Pp. 2117-2129.

8. Panhwar Q.K., Memon Sh. Synthesis, Spectral Characterization and Antioxidant Activity of Tin(II)-Morin Complex // Pakistan Journal of Analytical and Environmental Chemistry. 2012. Vol. 13, N2. Pp. 159-168.

9. Panhwar Q.K., Memon Sh. Synthesis and properties of zirconium(IV) and molybdate(II) morin complexes // Journal of Coordination Chemistry. 2012. Vol. 65, N7. Pp. 1130-1143.

10. Pereira R.M.S., Andrades N.E.D., Paulino N., Sawaya A.C.H.F., Eberlin M.N., Marcucci M.C., Favero G.M., Novak E.M., Bydlowski S.P. Synthesis and Characterization of a Metal Complex Containing Naringin and $\mathrm{Cu}$, and its Antioxidant, Antimicrobial, Antiinflammatory and Tumor Cell Cytotoxicity // Molecules. 2007. Vol. 12. Pp. 1352-1366.

11. Guo M., Perez C., Wei Y., Rapoza E., Su G., Bou-Abdallah F., Chasteen N.D. Iron-binding properties of plant phenolics and cranberry,s bio-effects // Dalton Transactions. 2007. Vol. 41. Pp. 4951-4961.

12. Mello L.D., Pereira R.M.S., Sawaya A.C.H.F., Eberlin M.N., Kubota L.T. Electrochemical and spectroscopic characterization of the interaction between DNA and Cu(II)-naringin complex // Journal of Pharmaceutical and Biomedical Analysis. 2007. Vol. 45. Pp. 706-713.

13. Roshal A.D., Sakhno T.V., Verezubova A.A., Ptiagina L.M., Musatov V.I., Wroblewska A., Blazejowski J. Structure, stability and spectral properties of complexes of flavones with metal ions of group II // Functional Materials. 2003. Vol. 10, N3. Pp. 419-426.

14. Костюк В.А., Потапович А.И. Биорадикалы и биоантиоксиданты. Минск, 2004. 174 с.

15. De Souza R.F., De Giovani W.F. Antioxidant properties of complexes of flavonoids with metal ions // Redox Report. 2004. Vol. 9, N2. Pp. 97-104.

16. Мельникова Н.Б., Иоффе И.Д., Царева Л.А. Взаимодействие биофлавоноидов с ацетатом меди (II) в водном растворе // Химия природных соединений. 2002. №1. С. 26-31.

17. Мельникова Н.Б., Иоффе И.Д. Взаимодействие дигидрокверцетина с ионами металлов в водных растворах их солей и в изотонических медицинских средах // Химия растительного сырья. 2001. №4. С. 25-33.

18. Щекатихина А.С., Курченко В.П. Спектрофотометрическая характеристика комплексов кверцетина, морина, таксифолина и силибинина с ионами меди (II) // Труды БГУ. 2011. Т. 6, №1. С. 76-85.

19. Moridani M.Y., Pourahmad J., Bui H., Siraki A., O'Brien P.J. Dietary flavonoid iron complexes as cytoprotective superoxide radical scavengers // Free Radical Biology \& Medicine. 2003. Vol. 34, №2. Pp. 243-253.

20. Бабкин В.А., Остроухова Л.А., Трофимова Н.Н. Биомасса лиственницы: от химического состава до инновационных продуктов. Новосибирск, 2011. 232 с.

21. Трофимова Н.Н., Бабкин В.А., Вакульская Т.И., Чупарина Е.В. Исследование методов синтеза, строения и свойств комплексов флавоноидов с ионами металлов. Сообщение 1. Синтез и установление строения комплексов и солей дигидрокверцетина с цинком, медью (II) и кальцием в водных растворах // Химия растительного сырья. 2012. № 2. С. 51-62.

22. Заявка на выдачу патента 2013121728 (РФ). Способ получения моно- и билигандных комплексных соединений ионов двухвалентных металлов- цинка, меди (II) и кальция с дигидрокверцетином, обладающих усиленной антиоксидантной активностью / Н.Н. Трофимова, В.А. Бабкин, Е.В. Столповская. 08.05.2013.

23. Заявка на выдачу патента 2013146457 (РФ). 17.10.2013.

24. Трофимова Н.Н., Столповская Е.В., Бабкин В.А. Исследование методов синтеза, строения и свойств комплексов флавоноидов с ионами металлов. Сообщение 2. Оптимизация реакции комплексообразования цинка с дигидрокверцетином в водной среде // Химия растительного сырья. 2013. №3. С. 73-79.

25. Трофимова Н.Н., Столповская Е.В., Бабкин В.А. Исследование методов синтеза, строения и свойств комплексов флавоноидов с ионами металлов. Сообщение 3. Изучение кинетики реакции комплексообразования меди с дигидрокверцетином // Химия растительного сырья. 2013. №4. С. 37-43.

26. Государственная фармакопея СССР: Вып. 2. Общие методы анализа. Лекарственное растительное сырье. МЗ СССР. 11-е изд., доп. М., 1989. 400 с.

27. Электрохимия металлов в неводных растворах / пер. с англ. ; под ред. Я.М. Колотырнина. М., 1974. 440 с. 
28. Damnjanovic B., Petrovic B., Dimitric-Marcovic J., Petkovic M. Comparison of MALDI-TOF mass spectra of $[\mathrm{PdCl}($ dien $)] \mathrm{Cl}$ and $[\mathrm{Ru}(\mathrm{en}) 2 \mathrm{Cl} 2] \mathrm{Cl}$ acquired with different matrices // Journal of the Serbian Chemical Society. 2011. Vol. 76, N12. Pp. 1687-1701.

29. Harborne J.B., Mabry T.J., Mabry H. The Flavonoids. London, 1975. 1204 p.

30. Вязникова М.Ю., Николаева С.С., Быков В.А., Яковлева Л.В., Руленко И.А., Тюкавкина Н.А., Колесник Ю.А. Исследование состояния воды в стандартном образце дигидрокверцетина и в новом фитопрепарате диквертине // Химико-фармацевтический журнал. 1997. Т. 31, №2. С. 42-45.

31. Селиванова И.А., Тюкавкина Н.А., Колесник Ю.А., Кулешова Л.Н., Хуторянский В.А., Баженов Б.Н., Сайботалов М.Ю. Исследование кристаллической структуры дигидрокверцетина // Химико-фармацевтический журнал. 1999. Т. 73, №4. С. 51-53.

32. Барбалат Ю.А., Власов Ю.Г., Демин В.А. и др. Новый справочник химика и технолога. Аналитическая химия. СПб., 2002. Ч. І. 964 с.

33. Казицына Л.А., Куплетская Н.Б. Применение УФ, ИК, ЯМР и масс-спектроскопии в органической химии. М., 1979. $240 \mathrm{c}$.

34. Сильверстейн Р., Басслер Г., Моррил Т. Спектрометрическая идентификация органических соединений. М., 1977. $590 \mathrm{c}$.

35. Тюкавкина Н.А., Чертков В.А., Баженов Б.Н., Белобородов В.Л., Селиванова И.А., Савватеев А.М. Физикохимическая характеристика дигидрокверцетина как стандартного образца // Актуальные проблемы создания новых лекарственных препаратов природного происхождения - Фитофарм. СПб., 2006. С. 338-342.

36. Плотников М.Б., Тюкавкина Н.А., Плотникова Т.М. Лекарственные препараты на основе диквертина. Томск, 2005. $228 \mathrm{c}$.

37. Столповская Е.В., Трофимова Н.Н., Бабкин В.А. Исследование методов синтеза, строения и свойств комплексов флавоноидов с ионами металлов. Сообщение 4. Изучение реакции комплексообразования ионов $\mathrm{Ca}^{2+}$ с дигидрокверцетином // Химия растительного сырья. В печати.

38. Argawal P.K., Schneider H.J. Depronation-induced 13-C NMR shifts in phenols and flavonoids // Tetrahedron Letters. 1983. Vol. 24. Pp. 177-180.

39. Janeiro P., Conduneanu O., Brett A.M.O. Chrysin and ( \pm )-Taxifolin Electrochemical Oxidation Mechanisms // Electroanalysis. 2005. Vol. 17, N12. Pp. 1059-1064.

40. SaitoA., Sugisawa A., Umegaki K. Comparison of photometric, electrochemical and post-column fluorescence detection for the determination of flavonoids by HPLC // Shokuhin Eiseigaku Zasshi. 2001. Vol. 42, N3. Pp. 174-178.

41. Jorgensen L., Madsen H., Thomsen M., Dragsted L., Skibsted L. Regeneration of phenolic antioxidants from phenoxyl radicals: an ESR and electrochemical study of antioxidant hierarchy // Free Radical Researsh. 1999. Vol. 30, N3. Pp. 207-220.

42. Матвеев Д.А., Арбузова Е.А., Крайкивский П.Б., Апрелкова Н.Ф., Хуторянский В.А., Крюкова К.М. Электрохимическое восстановление дигидрокверцетина на ртутном электроде // Электрохимия. 2011. Т. 47, №9. C. 1096-1102.

43. Баженов Б.Н., Елисеева Г.Д., Золотарев Е.Е., Кашевский А.В., Сафронов А.Ю., Финкельштейн Б.Л. Антиоксидантные и электрохимические свойства моносукцината дигидрокверцетина - нового водорастворимого производного природного флавоноида // Химия растительного сырья. 2013. №3. С. 107-112.

Поступило в редакциию 29 августа 20142.

После переработки 12 сентября 2014 г. 
Trofimova N.N. ${ }^{\text {* }}$, Stolpovskaya E.V. ${ }^{l}$, Babkin V.A. ${ }^{l}$, Fedorov S.V. ${ }^{l}$, Kalabin G.A. ${ }^{2}$, Goryainov S.V. ${ }^{2}$, Zolotarev E.E. ${ }^{l}$, Safronov A.Yu. ${ }^{3}$, Kashevsky A.V. ${ }^{3}$, Zhitov R.G. ${ }^{3}$ THE STRUCTURE AND ELECTROCHEMICAL PROPERTIES OF METAL COMPLEXES WITH DIHYDROQUERTCETIN

${ }^{1}$ A.E. Favorsky Institute of Chemistry, Siberian Branch, Russian Academy of Sciences, Favorsky Str., 1, Irkutsk, 664033

(Russia),e-mail: natrof@inbox.ru

${ }^{2}$ People Frendship University of Russia, Miklukho-Maklaya Str., 6, Moscow, 117198 (Russia)

${ }^{3}$ Irkutsk State University, K. Marks Str., 1, Irkutsk, 664033 (Russia)

The structures of the zinc (2), copper (II) (3) and calcium (4) complexes with trans-2R, 3R-dihydroquercetin (1) have been elucidated by IR, 2D NMR, mass spectrometry DART techniques, term gravimetric analyses with using data elemental and microscopic energy dispersive X-ray analyses. The redox properties of complexes 2-4 were studied by cyclic voltammetry on graphite electrode in DMSO.

Kewwords: complex compounds of zinc, copper (II), calcium with dihydroquercetin, structure, cyclic voltammetry.

\section{References}

1. Chernaia N.V., Matiashov V.G. Zhurnal analiticheskoi khimii, 1975, vol. XXX, no. 4, pp. 698-702. (in Russ.)

2. Makashev Iu.A., Sharonov V.P., Mironov V.E., Makasheva I.E., Blokhin V.V. Zhurnal obshchei khimii, 1975, vol. 45, no. 12, pp. 2748. (in Russ.)

3. Makasheva I.E., Mirzaeva L.K., Golovkina M.T. Zhurnal obshchei khimii, 1974, vol. 44, no. 7, pp. 1570-1575. (in Russ.)

4. De Souza R.F.V., De Giovani W.F. Spectrochimica Acta Part A, 2005, vol. 61, pp. 1985-1990.

5. Nest G.Le, Caille O., Woudstra M., Roche S., Guerlesquin F., Lexa D. Inorganica Chimica Acta, 2004, vol. 357, pp. $775-784$.

6. Panhwar Q.K., Memon Sh., Bhanger M.I. Journal of Molecular Structure, 2010, vol. 967, pp. 47-53.

7. Panhwar Q.K., Memon Sh. Journal of Coordination Chemistry, 2011, vol. 64, no. 12, pp. 2117-2129.

8. Panhwar Q.K., Memon Sh. Pakistan Journal of Analytical and Environmental Chemistry, 2012, vol. 13, no. 2, pp. 159-168.

9. Panhwar Q.K., Memon Sh. Journal of Coordination Chemistry, 2012, vol. 65, no. 7, pp. 1130-1143.

10. Pereira R.M.S., Andrades N.E.D., Paulino N., Sawaya A.C.H.F., Eberlin M.N., Marcucci M.C., Favero G.M., Novak E.M., Bydlowski S.P. Molecules, 2007, vol. 12, pp. 1352-1366.

11. Guo M., Perez C., Wei Y., Rapoza E., Su G., Bou-Abdallah F., Chasteen N.D. Dalton Transactions, 2007, vol. 41, pp. 4951-4961.

12. Mello L.D., Pereira R.M.S., Sawaya A.C.H.F., Eberlin M.N., Kubota L.T. Journal of Pharmaceutical and Biomedical Analysis, 2007, vol. 45, pp. 706-713.

13. Roshal A.D., Sakhno T.V., Verezubova A.A., Ptiagina L.M., Musatov V.I., Wroblewska A., Blazejowski J. Functional Materials, 2003, vol. 10, no. 3, pp. 419-426.

14. Kostiuk V.A., Potapovich A.I. Bioradikaly i bioantioksidanty. [Bioradicals and bioantioxidants]. Minsk, 2004, 174 p. (in Russ.).

15. De Souza R.F., De Giovani W.F. Redox Report, 2004, vol. 9, no. 2, pp. 97-104.

16. Mel'nikova N.B., Ioffe I.D., Tsareva L.A. Khimiia prirodnykh soedinenii, 2002, no. 1, pp. 26-31. (in Russ.).

17. Mel'nikova N.B., Ioffe I.D. Khimiia rastitel'nogo syria, 2001, no. 4, pp. 25-33. (in Russ.).

18. Shchekatikhina A.S., Kurchenko V.P. Trudy BGU, 2011, vol. 6, no. 1, pp. 76-85. (in Russ.).

19. Moridani M.Y., Pourahmad J., Bui H., Siraki A., O'Brien P.J. Free Radical Biology \& Medicine, 2003, vol. 34, no. 2, pp. 243-253.

20. Babkin V.A., Ostroukhova L.A., Trofimova N.N. Biomassa listvennitsy: ot khimicheskogo sostava do innovatsionnykh produktov. [Biomass larch: the chemical composition to innovative products]. Novosibirsk, 2011, 232 p. (in Russ.).

21. Trofimova N.N., Babkin V.A., Vakul'skaia T.I., Chuparina E.V. Khimiia rastitel'nogo syr'ia, 2012, no. 2, pp. 51-62. (in Russ.).

22. The application for a patent 2013121728 (RU). 08.05.2013. (in Russ.).

23. The application for a patent 2013146457 (RU). 17.10.2013. (in Russ.).

24. Trofimova N.N., Stolpovskaia E.V., Babkin V.A. Khimiia rastitel'nogo syr'ia, 2013, no. 3, pp C. 73-79. (in Russ.).

25. Trofimova N.N., Stolpovskaia E.V., Babkin V.A. Khimiia rastitel'nogo syr'ia, 2013, no.4, pp. 37-43. (in Russ.).

26. Gosudarstvennaia farmakopeia SSSR: Vyp. 2. Obshchie metody analiza. Lekarstvennoe rastitel'noe syr'e. MZ SSSR. [State Pharmacopoeia of the USSR: Vol. 2. General methods of analysis. Herbal drugs. USSR Ministry of Health]. 11 ed. Moscow, 1989, 400 p. (in Russ.).

27. Elektrokhimiia metallov $\mathrm{v}$ nevodnykh rastvorakh. [Electrochemistry metals in nonaqueous solutions] Ed. Ia.M. Kolotyrnin. Moscow, 1974, 440 p. (in Russ.).

28. Damnjanovic B., Petrovic B., Dimitric-Marcovic J., Petkovic M. Journal of the Serbian Chemical Society, 2011, vol. 76, no. 12, pp. 1687-1701.

29. Harborne J.B., Mabry T.J., Mabry H. The Flavonoids. London, 1975. 1204 p.

\footnotetext{
* Corresponding author.
} 
30. Viaznikova M.Iu., Nikolaeva S.S., Bykov V.A., Iakovleva L.V., Rulenko I.A., Tiukavkina N.A., Kolesnik Iu.A. Khimiko-farmatsevticheskii zhurnal, 1997, vol. 31, no. 2, pp. 42-45. (in Russ.).

31. Selivanova I.A., Tiukavkina N.A., Kolesnik Iu.A., Kuleshova L.N., Khutorianskii V.A., Bazhenov B.N., Saibotalov M.Iu. Khimiko-farmatsevticheskii zhurnal, 1999, vol. 73, no. 4, pp. 51-53. (in Russ.).

32. Barbalat Iu.A., Vlasov Iu.G., Demin V.A. et al. Novyi spravochnik khimika i tekhnologa. Analiticheskaia khimiia. [The new directory chemist and technologist. analytical chemistry]. St. Petersburg, 2002, part I, 964 p. (in Russ.).

33. Kazitsyna L.A., Kupletskaia N.B. Primenenie UF, IK, IaMR i mass-spektroskopii v organicheskoi khimii. [Application of UV, IR, NMR and mass spectrometry in organic chemistry]. Moscow, 1979, 240 p. (in Russ.).

34. Sil'verstein R., Bassler G., Morril T. Spektrometricheskaia identifikatsiia organicheskikh soedinenii. [Spectrometric identification of organic compounds]. Moscow, 1977, 590 p. (in Russ.).

35. Tiukavkina N.A., Chertkov V.A., Bazhenov B.N., Beloborodov V.L., Selivanova I.A., Savvateev A.M. Aktual'nye problemy sozdaniia novykh lekarstvennykh preparatov prirodnogo proiskhozhdeniia - Fitofarm. [Actual problems of creating new drugs of natural origin - Phytopharm]. St. Petersburg, 2006, pp. 338-342. (in Russ.).

36. Plotnikov M.B., Tiukavkina N.A., Plotnikova T.M. Lekarstvennye preparaty na osnove dikvertina. [Drugs based on Diquertin]. Tomsk, 2005, 228 p. (in Russ.).

37. Stolpovskaia E.V., Trofimova N.N., Babkin V.A. Khimiia rastitel'nogo syr'ia. (in Press.). (in Russ.).

38. Argawal P.K., Schneider H.J. Tetrahedron Letters, 1983, vol. 24, pp. 177-180.

39. Janeiro P., Conduneanu O., Brett A.M.O. Electroanalysis, 2005, vol. 17, no. 12, pp. 1059-1064.

40. SaitoA., Sugisawa A., Umegaki K. Shokuhin Eiseigaku Zasshi, 2001, vol. 42, no. 3, pp. 174-178.

41. Jorgensen L., Madsen H., Thomsen M., Dragsted L., Skibsted L. Free Radical Researsh., 1999, vol. 30, no. 3, pp. 207-220.

42. Matveev D.A., Arbuzova E.A., Kraikivskii P.B., Aprelkova N.F., Khutorianskii V.A., Kriukova K.M. Elektrokhimiia, 2011, vol. 47, no. 9, pp. 1096-1102. (in Russ.).

43. Bazhenov B.N., Eliseeva G.D., Zolotarev E.E., Kashevskii A.V., Safronov A.Iu., Finkel'shtein B.L. Khimiia rastitel'nogo syr'ia, 2013, no. 3, pp. 107-112. (in Russ.). 
